\title{
Program Berkelanjutan Membantu Mitra KWT Melati Mini untuk Tumbuh Kembang dengan Usaha Ternak Puyuh di Koto Lua Kecamatan Pauh, Padang
}

\author{
Mirnawati ${ }^{1}$, Yurniwati ${ }^{2}$, dan Zuhri Syam ${ }^{3}$ \\ ${ }_{1}^{1}$ Fakultas Peternakan, Universitas Andalas, Kampus Limau Manis, Padang, 25163. Indonesia \\ 2Fakultas Ekonomi, Universitas Andalas, Kampus Limau Manis, Padang, 25163. Indonesia \\ ${ }^{3}$ Fakultas MIPA, Universitas Andalas, Kampus Limau Manis, Padang, 25163. Indonesia \\ E-mail: mirnawati@ansci.unand.ac.id
}

Keywords: community services, livestock, quail farm, socioeconomic

Kata Kunci: pengabdian masyarakat, peternakan, sosial ekonomi, ternak puyuh

\begin{abstract}
The problems faced by farmers are the high price of feed and the socio-economic problems of livestock. The solutions offered are counseling, application of ration technology and assistance related to science of feed (nutritious and low-priced feed formulations), application of ration formulas by breeders, guidance and counseling on socio-economic problems for instance entrepreneurship, marketing and business development. The objective of the activity is to increase farmers' knowledge about rations (low price ration formulations) and socio-economic problems of livestock. Meanwhile, the benefit of the activity is to help develop the quail farming micro business as a form of institutional care for the community around the campus and to improve community service performance and the application of University's innovation. The stages of the activity implementation began with counseling on quail farming, counseling on rations and application of ration formulation technology, and evaluation. The results of the activity indicated that the extension activities carried out had increased farmers' knowledge about low-priced feed and ration formulations. In addition, counseling in the economic sector is able to provide knowledge to farmers about entrepreneurship for their livestock businesses.
\end{abstract}

\begin{abstract}
ABSTRAK
Permasalahan yang dihadapi peternak adalah harga pakan yang mahal dan masalah sosial ekonomi peternakan. Solusi yang ditawarkan adalah penyuluhan, percontohan teknologi formulasi ransum dan pendampingan yang berkaitan dengan aplikasi ransum (formulasi pakan bergizi dan harga murah), penerapan formula ransum oleh peternak, bimbingan dan penyuluhan masalah sosial ekonomi (kewirausahaan, pemasaran dan pengembangan usaha). Tujuan kegiatan adalah meningkatkan pengetahuan peternak tentang ransum dan memberi pengetahuan tentang masalah sosial ekonomi peternakan. Sedangkan manfaat kegiatan adalah membantu perkembangan usaha mikro peternakan puyuh sebagai wujud kepedulian institusi terhadap masyarakat sekitar kampus dan meningkatkan kinerja pengabdian masyarakat dan penerapan inovasi Perguruan Tinggi. Tahapan pelaksanaan kegiatan dimulai dengan penyuluhan tentang usaha peternakan puyuh, tentang ransum dan penerapan teknologi formulasi ransum, bimbingan/pembinaan, evaluasi dan pelestarian program. Hasil kegiatan menunjukkan bahwa kegiatan yang dilakukan telah meningkatkan pengetahuan peternak tentang pakan dan formulasi ransum. Aplikasi ransum dapat meningkatkan keuntungan peternak karena berharga lebih murah dari ransum komersil yang dijual di Poulty Shop. Disamping itu, penyuluhan dibidang ekonomi, mampu memberikan pengetahuan kepada peternak tentang kewirausahaan dan pembuatan pembukuan sederhana untuk usaha peternakan puyuh.
\end{abstract}




\section{PENDAHULUAN}

Kelompok Wanita Tani (KWT) Melati Mini adalah KWT yang bergerak dalam bidang produksi pertanian dimana salah satu unit usahanya adalah peternakan puyuh petelur. Kelompok didirikan tahun 2014 dengan jumlah anggota kelompok sebanyak 23 orang dengan masing-masing pemilikan ternak puyuh 500 ekor yang berasal dari bantuan Baziz kota Padang Tahun 2018. Disamping memeliharan ternak puyuh, usaha anggota KWT adalah bidang pertanian (sawah, kebun sayuran, buah-buahan dll). Usaha dikelola secara kekeluargaan dengan manajemen sederhana dengan anggota/pekerja berasal dari anggota keluarga. Saat ini, sebanyak 5 orang anggota kelompok telah meningkatkan jumlah ternak puyuh menjadi 2000 - 3000 ekor bahkan ada beberapa orang anggota kelompok akan terus mengembangkan usaha. Pemasaran telur dilakukan secara langsung kepada pedagang atau melalui warung-warung yang ada di desa dalam packing berisi 20 butir/pack dengan harga Rp. 5.000,-. Sebagian telur puyuh juga dipasarkan melalui Koperasi Pemasaran Mandiri dan Merdeka (KMDM), Pauh, Padang.

Ditinjau dari segi produksi, usaha peternakan puyuh yang dikelola oleh kelompok menghadapi masalah mahalnya harga pakan sehingga keuntungan yang diperoleh peternak rendah. Permasalahan yang dihadapi peternak puyuh di Kelurahan Koto Lua ini hampir sama dengan permasalahan yang dihadapi oleh beberapa usaha peternakan skala besar di Kabupaten 50 Kota yaitu mahalnya harga pakan. Ditinjau dari segi pakan, unggas lokal seperti puyuh, sebenarnya dapat memanfaatkan bahan pakan lokal untuk mengurangi biaya produksi karena biaya terbesar dari proses produksi pada ternak unggas adalah biaya pakan.

Hasil Penelitian Mirnawati, dkk (2018a,b) dan Paten No.SID201805255 (Mirnawati, 2018) menunjukkan bahwa berbagai bahan pakan lokal inkonvensional seperti bungkil inti sawit, kulit ubi kayu dan kulit pisang dapat dijadikan sebagai bahan makanan ternak puyuh melalui penerapan teknologi fermentasi yang dapat meningkatkan kualitas bahan pakan lokal tersebut. Begitu juga dengan penggunaan bahan limbah lain seperti limbah ikan dan keong mas yang juga cukup tersedia di desa bahkan sudah merupakan hama, dapat menggantikan 75 \% kebutuhan protein hewani untuk pakan unggas (Mirnawati, 2001).

Ditinjau dari aspek manejemen, usaha peternakan puyuh oleh kelompok masih dikelola secara tradisional, pembukuan hanya berisi catatan uang masuk dan uang keluar saja, tidak ada rencana (program) tentang pengembangan usaha dalam jangka panjang dan langkah-langkah atau strategi peningkatan usaha.

Permasalahan yang dihadapi di bidang produksi karena mahalnya harga ransum karena peternak bergantung kepada ransum pabrik yang dijual di poultry shop dengan harga cukup tinggi. Selain itu, pengetahuan peternak tentang kewirausahaan, pemasaran dan pembukuan masih kurang. Peternak juga belum memiliki rencana jangka panjang untuk pengembangan usaha karena keterbatasan pengetahuan yang memerlukan pendampingan untuk pengembangan usaha pada masa mendatang.

Untuk mengatasi permasalahan yang dihadapi peternak diatas, khususnya masalah mahalnya harga ransum, kepada peternak perlu diberikan pelatihan mengenai formulasi ransum harga murah dengan bahan lokal yang mudah didapat dan mampu diformulasikan sendiri oleh peternak dengan mudah. Berdasarkan latar belakang diatas, dilakukan kegiatan pengabdian kepada masyarakat dengan judul "Program Berkelanjutan Membantu Mitra KWT Melati Mini untuk Tumbuh Kembang dengan Usaha Ternak Puyuh di Koto Lua Kecamatan Pauh”.

Tujuan yang ingin dicapai dari kegiatan ini adalah:

a. Mewujudkan kepedulian Universitas Andalas sebagai Perguruan Tinggi yang peduli masyarakat sekitar kampus.

b. Aplikasi ilmu pengetahuan hasil inovasi Perguruan Tinggi kepada masyarakat sebagai pengguna untuk peningkatan kesejahteraan. 
c. Meningkatkan keterampilan peternak dalam mengolah/memformulasikan ransum sendiri berharga murah untuk ternak puyuh mereka dalam rangka mengurangi biaya produksi.

d. Meningkatkan keuntungan usaha agar kesejahteraan peternak meningkat.

\section{METODE}

Pelaksanaan kegiatan dilakukan dengan beberapa metode yaitu:

a. Penyuluhan

Penyuluhan bertujuan untuk meningkatkan pengetahuan peternak terutama tentang masalah pakan.Selain itu juga diberikan penyuluhan tentang aspek social ekonomi meliputi pemasaran, kewirausahaan dan pembukuan usaha.

b. Pelatihan/aplikasi pembuatan ransum harga murah

Setelah penyuluhan, peternak puyuh kelompok KWT diberi pelatihan meliputi pelatihan teknologi pengolahan bahan pakan non konvesional (limbah), penyusunan/formulasi ransum, pelatihan kewirausahaan dan pelatihan motivasi. Selain itu juga diberi pelatihan penyusunan ransum harga murah menggunakan bahan-bahan lokal seperti jagung, dedak, dan konsentrat 126. Jumlah bahan yang digunakan dan kandungan gizi ransum pelatihan dapat dilihat pada Tabel 1. Formulasi ransum yang digunakan adalah ransum puyuh petelur dengan kandungan protein ransum $19 \%$.

Tabel 1. Susunan Ransum Pelatihan dan Kandungan Gizi Ransum

\begin{tabular}{lclc}
\hline Bahan Ransum & Jumlah (Kg) & \multicolumn{2}{c}{ Kandungan Gizi Ransum } \\
\hline Konsentrat 126 CP & 50 & Protein (\%) & 19 \\
Jagung & 50 & Energy (kkal) & 2800 \\
Dedak & 50 & & \\
Mineral B12 & 2 & & \\
Top Mix & 0.5 & & \\
\hline
\end{tabular}

Sumber: Hasil analisis laboratorium Nutrisi Non Ruminansia (2020)

c. Penerapan ransum harga murah pada puyuh peternak

Ransum formulasi pelatihan penyusunan ransum diatas, diaplikasikan pada 100 ekor puyuh peternak (R1) sedangkan untuk pembanding digunakan 100 ekor puyuh yang diberi ransum yang biasa digunakan oleh peternak yaitu ransum komersil (R2). Pengamatan dilakukan selama 15 hari. Paramater yang diukur adalah produksi telur dan konsumsi ransum. Untuk mengetahui respon ternak puyuh terhadap ransum pelatihan dan ransum komersial, digunakan uji t ( $\mathrm{t}$-test) menurut Steel and Torry (2002) dengan rumus $\left.t-h i t=\left(Y_{1}-Y 2\right) \sqrt{ }\left(S_{1}^{2} / n 1\right)+S_{2}^{2} / n 2\right)$.

\section{d. Bimbingan dan pembinaan}

Setelah mendapatkan penyuluhan dan pelatihan, peternak dibimbing dan dibina agar usaha peternakan puyuh mereka menerapkan teknologi pengolahan pakan dapat berjalan dengan baik sesuai dengan yang direncanakan. Bimbingan dan pembinaan berlangsung selama \pm 1 bulan.

\section{e. Monitoring}

Agar kegiatan berjalan dengan baik, dilakukan monitoring secara berkala $(1 \mathrm{x} 1 \mathrm{minggu}$ selama 2 bulan). Pada saat monitoring, diadakan diskusi dan konsultasi untuk mencari solusi 
dari berbagai kendala yang dihadapi baik dalam hal teknis peternakan maupun dalam hal pengembangan usaha.

\section{f. Evaluasi/pelaporan}

Pada akhir kegiatan dilakukan evaluasi dan penyiapan program pengembangan mitra untuk 3 tahun ke depan dan akan disusun sebuah laporan akhir sebagai pertanggungjawaban terhadap kegiatan yang telah dilaksanakan.

\section{HASIL DAN PEMBAHASAN}

\section{a. Penyuluhan}

Penyuluhan bertujuan untuk meningkatkan pengetahuan peternak terutama tentang masalah pakan. Selain itu juga diberikan penyuluhan tentang aspek sosial ekonomi meliputi pemasaran, kewirausahaan dan pembukuan usaha. Penyuluhan telah dilaksanakan pada tanggal 16 Desember 2020 bertempat di rumah salah seorang anggota kelompok di Koto Lua Kecamatan Pauh, Kota Padang. Peternak cukup antusias mengikuti kegiatan penyuluhan yang dilakukan. Pada saat penyuluhan peternak mengajukan pertanyaan tentang formula ransum harga murah dan menurunnya keuntungan karena harga pakan yang mahal. Untuk dapat bertahan ditengah situasi harga pakan yang mahal, kepada peternak diharapkan tetap bertahan dan terus berusaha karena tantangan dalam usaha peternakan cukup banyak, yang salah satu diantaranya adalah harga pakan yang mahal. Peternak yang tangguh adalah peternak yang mampu bertahan dalam berbagai kondisi lingkungan usaha yang berat seperti mahalnya harga ransum.

\section{b. Percontohan pembuatan ransum}

Pelatihan yang diberikan meliputi pelatihan teknologi pengolahan pakan (penyusunan/formulasi ransum), pelatihan kewirausahaan dan pelatihan motivasi. Pelatihan teknologi pengolahan pakan diberikan oleh Prof. Dr. Ir. Mirnawati MS (ketua Tim Pelaksana), pelatihan kewirausahaan dan motivasi usaha diberikan oleh Dr. Yurniwati SE MSi (anggota Tim Pelaksana dari Fakultas Ekonomi Universitas Andalas). Sebelum penyuluhan/percontohan, dipersiapkan materi-materi/brosur tentang kegiatan penyuluhan/pelatihan yang akan diberikan. Ditinjau dari aspek pengolahan pakan, kepada peternak diberikan pelatihan/ percontohan tentang formulasi/penyusunan ransum agar diperoleh ransum yang berkualitas dan berharga murah. Percontohan dan aplikasi ransum juga telah dilaksanakan pada tanggal 16 Desember 2020 bertempat di rumah salah seorang anggota kelompok di Koto Lua Kecamatan Pauh, Kota Padang. Hasil perhitungan kandungan gizi terhadap ransum percontohan menunjukkan bahwa ransum memenuhi kandungan gizi untuk puyuh petelur dengan kandungan protein ransum 19\%. Hal ini sesuai dengan yang disarankan SNI (2006) bahwa kebutuhan protein kasar ternak puyuh minimal 17\% dengan ketersediaan phosphor minimal $0.4 \%$.

\section{c. Aplikasi penggunaan ransum percontohan pada ternak puyuh}

Pada kegiatan ini membandingkan antara ransum yang disusun sendiri yaitu menggunakan bahan lokal dengan ransum komersil terhadap konsumsi ransum dan produksi telur puyuh selama kegiatan. Rataan konsumsi ransum dan produksi telur puyuh dengan penggunaan dua jenis ransum yang berbeda, yakni ransum percontohan (R1) dan komersil (R2) dapat dilihat pada Tabel 2 dan 3. 
Tabel 2. Rataan konsumsi ransum selama kegiatan (g/ekor/hari)

\begin{tabular}{ccc}
\hline Hari ke- & Ransum Percontohan (R1) & Ransum Komersil (R2) \\
\hline 1 & 21.88 & 21.83 \\
2 & 21.79 & 21.86 \\
3 & 21.80 & 21.80 \\
4 & 21.90 & 21.82 \\
5 & 21.84 & 21.89 \\
6 & 21.90 & 21.87 \\
7 & 21.91 & 21.84 \\
8 & 21.92 & 21.85 \\
9 & 21.92 & 21.87 \\
10 & 21.80 & 21.86 \\
11 & 21.86 & 21.76 \\
12 & 21.80 & 21.89 \\
13 & 21.87 & 21.68 \\
14 & 21.82 & 21.88 \\
15 & 21.90 & 21.78 \\
\hline Rataan & 21.86 & 21.83 \\
Sd & 0.05 & 0.06 \\
SE & 0.01 & 0.02 \\
\hline
\end{tabular}

Sumber: Data pengamatan harian selama kegiatan

Tabel 3. Rataan produksi telur puyuh selama kegiatan (\%)

\begin{tabular}{ccc}
\hline Hari & Ransum Percontohan (R1) & Ransum Komersil (R2) \\
\hline 1 & 87 & 82 \\
2 & 89 & 82 \\
3 & 89 & 82 \\
4 & 89 & 84 \\
5 & 81 & 84 \\
6 & 83 & 85 \\
7 & 82 & 85 \\
8 & 82 & 83 \\
9 & 88 & 87 \\
10 & 83 & 85 \\
11 & 84 & 83 \\
12 & 85 & 84 \\
13 & 84 & 85 \\
14 & 83 & 82 \\
15 & 85 & 84 \\
\hline Rataan & 84.93 & 83.80 \\
Sd & 2.79 & 1.47 \\
SE & 0.72 & 0.38 \\
\hline
\end{tabular}

Sumber: Data produksi telur puyuh harian selama kegiatan

Dari tabel 2 di atas terlihat bahwa rataan konsumsi ransum R1 dan R2 adalah 21.86 dan $21.83 \mathrm{~g} /$ ekor/hari. Berdasarkan analisis uji t menunjukkan bahwa konsumsi ransum percontohan (R1) dan konsumsi ransum komersil (R2) memberikan pengaruh berbeda tidak 
nyata $(\mathrm{P}>0.05)$. Berbeda tidak nyatanya konsumsi ransum kedua perlakuan ini disebabkan energi metabolisme kedua ransum ini sama yaitu $2.800 \mathrm{kkal} / \mathrm{kg}$ ransum. Hal ini sesuai dengan pernyataan Wahyu (2004) bahwa konsumsi ransum dipengaruhi oleh energi metabolisme ransum. Konsumsi ransum diatas merupakan konsumsi ransum standar untuk ternak puyuh yang sedang berproduksi. Hal ini sesuai dengan pendapat Makinde et al., (2014) yang menyatakan bahwa konsumsi ransum puyuh adalah berkisar antara 22 - $27 \mathrm{~g} /$ ekor/hari.

Dari tabel 3 di atas terlihat bahwa produksi telur puyuh ransum yang disusun sendiri dari bahan lokal saat pelatihan (R1) adalah $84.93 \%$ sedangkan produksi telur pada ransum komersil (R2) adalah $83.80 \%$. Persentase produksi telur diatas sudah cukup baik yaitu diatas $80 \%$. Hal ini sesuai dengan pendapat Tetty (2002) yang menyatakan bahwa puncak produksi telur puyuh adalah diatas $80 \%$ yang dapat dicapai pada minggu ke 13 . Hasil uji t ( $t$ test) antara ransum $\mathrm{R} 1$ dan R2 menunjukkan bahwa tidak ada perbedaan produksi telur antara R1 dan R2 $(\mathrm{P}<0.05)$. Hal ini disebabkan karena kandungan gizi kedua ransum ini sama dengan kandungan protein 19\%. Hal ini sesuai dengan pendapat Anggorodi (1995) bahwa produksi telur dipengaruhi oleh kandungan protein ransum karena 50\% berat kering telur merupakan protein. Berbeda tidak nyatanya produksi telur antara R1 dan R2 juga disebabkan konsumsi ransum kedua perlakuan ini sama. Konsumsi yang sama akan memberikan produksi yang sama sesuai dengan pendapat Rasyaf (2002) bahwa produksi telur dipengaruhi oleh konsumsi ransum, terutama pada konsumsi protein. Ditambahkan oleh Anggorodi (1995) bahwa yang mempengaruhi produksi telur dalah kandungan protein dari makanan sebab $50 \%$ berat kering dari telur terdiri dari protein.

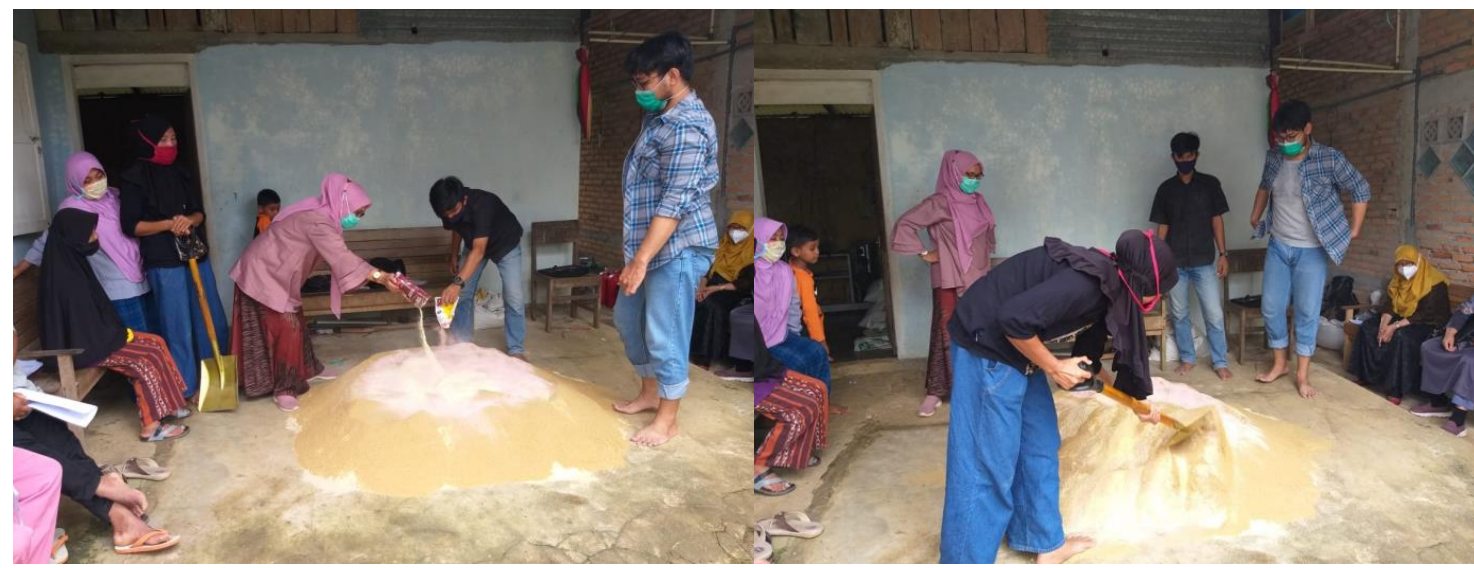

Gambar 1. Proses pengadukan bahan pakan penyusun ransum percontohan

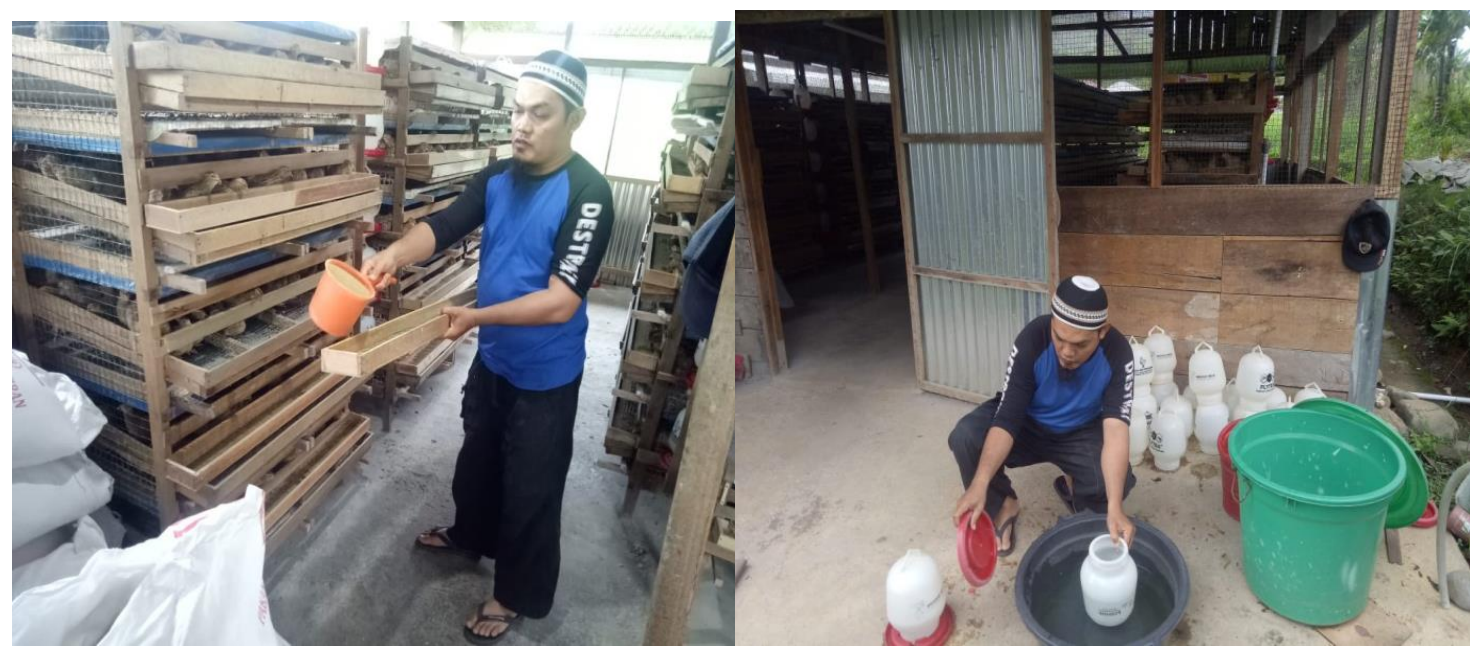

Gambar 2. Pemberian pakan ternak puyuh 


\section{d. Penyuluhan bidang ekonomi dan pemasaran}

Telah dilakukan penyuluhan di bidang ekonomi, pemasaran dan kewirausahaan. Pada kegiatan penyuluhan telah disampaikan sifat-sifat yang harus dimiliki oleh seorang pengusaha agar usaha berkembang dengan baik seperti tekun, tahan terhadap berbagai tantangan, jujur, kreatif dll. Disamping itu, kepada peternak mitra juga disampaikan bahwa untuk meningkatkan keuntungan, perlu diversifikasi usaha dan peningkatan populasi agar jumlah ternak yang dimiliki melampaui titik impas sehingga kegiatan usaha dapat memberikan keuntungan. Selain itu, untuk menambah pendapatan peternak, faeces/kotoran ternak juga dapat diolah menjadi pupuk organik.

\section{e. Bimbingan dan pembinaan}

Setelah mendapatkan penyuluhan dan pelatihan, peternak dibimbing dan dibina agar usaha peternakan puyuh mereka yang menerapkan pakan yang diformulasikan dapat berjalan dengan baik sesuai dengan yang direncanakan.

\section{f. Monitoring}

Agar kegiatan berjalan dengan baik, dilakukan monitoring secara berkala. Pada saat monitoring, diadakan diskusi dan konsultasi untuk mencari solusi dari berbagai kendala yang dihadapi baik dalam hal teknis peternakan, khususnya dalam aplikasi ransum maupun dalam hal pengembangan usaha.

Untuk mensukseskan pelaksanaan program pengabdian kepada masyarakat ini, peternak mitra Kelompok Peternakan Puyuh KWT Melati Mini diharapkan berpartisipasi aktif dalam beberapa hal, antara lain :

a. Keseriusan mengikuti rangkaian kegiatan

Seluruh rangkaian kegiatan yang dilaksanakan mulai dari penyuluhan tentang pakan ternak puyuh, penyuluhan kewirausahaan, pelatihan, pembinaan, monitoring dan evaluasi yang dilaksanakan oleh Tim Pelaksana telah dapat terlaksana dengan baik. Hal ini berarti bahwa, setiap anggota kelompok peternak mitra antusias dan serius dalam mengikuti rangkaian kegiatan yang dilaksanakan sehingga tujuan akhir kegiatan untuk memberdayakan kelompok menjadi mandiri akan dapat dicapai dengan baik.

\section{b. Motivasi harus tinggi}

Keinginan untuk meraih sukses dalam beternak dan dapat mengatasi persoalan-persoalan yang dihadapi hanya dapat dicapai jika ada motivasi yang kuat untuk mengembangkan usaha. Oleh sebab itu, penyuluhan kewirausahan dan motivasi usaha yang diberikan diharapkan dapat membangkitkan usaha peternak puyuh di KWT Melati Mini di Kecamatan Pauh, Kota Padang.

\section{c. Keberlanjutan program pengembangan pada 3-5 tahun ke depan}

Pengembangan KWT Melati Mini menjadi kelompok yang maju dan mandiri memerlukan pembinaan dan pendampingan minimal selama 3 tahun. Pembinaan dan pendampingan diharapkan dapat menjadikan peternak KWT Melati Mini menjadi kelompok tani yang mandiri dan berkembang dengan baik. Oleh sebab itu, kepada setiap anggota kelompok diharapkan memiliki semangat yang tinggi untuk pengembangan usaha pada masa mendatang dengan tujuan akhir menjadi kelompok yang mandiri. Perkembangan usaha diharapkan meningkatkan pendapatan dengan tujuan akhir meningkatkan kesejahteraan peternak anggota kelompok KWT Melati Mini Koto Lua Kecamatan Pauh, Kota Padang. Pada pelaksanaan kegiatan belum ditemukan hambatan yang berarti dan kegiatan yang dilakukan cukup memberikan dampak kepada timbulnya motivasi usaha peternakan puyuh yang dilakukan berkembang dengan baik. 


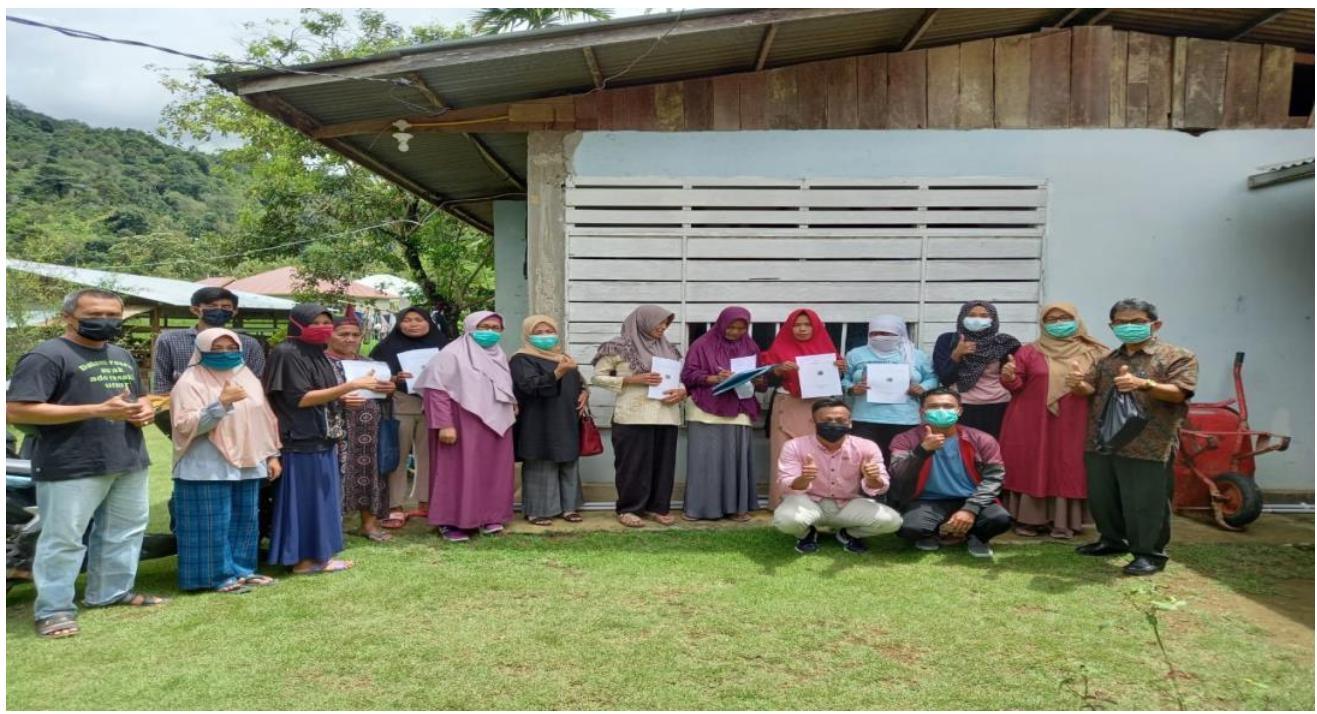

Gambar 3. Anggota kelompok tani sebagai mitra kegiatan

\section{KESIMPULAN}

Kegiatan penyuluhan dan percontohan yang dilakukan cukup menarik minat peternak dan peternak cukup antusias mengikuti kegiatan ini. Penerapan formulasi ransum percontohan dapat menurunkan harga ransum sehingga keuntungan peternak bisa ditingkatkan. Agar usaha peternakan puyuh berkembang dengan baik perlu dilakukan pembinaan berkelanjutan, khususnya aplikasi ransum harga murah melalui pembuatan rumah pakan dengan peralatan pengolahan ransum dan pembinaan pemasaran berkelanjutan. Disamping itu, kegigihan dan ketekunan peternak diperlukan dalam menghadapi berbagai kendala dan perlu dilakukan diversifikasi produk untuk meningkatkan keuntungan usaha peternakan.

\section{UCAPAN TERIMA KASIH}

Penulis mengucapkan terima kasih kepada Lembaga Penelitian dan Pengabdian kepada Masyarakat Universitas Andalas yang telah menyediakan dana untuk kegiatan pengabdian masyarakat ini melalui Kontrak No. T/87/UN.16.17/PM-PKM-MUB/LPPM/2020. Ucapan terima kasih juga dihaturkan untuk Kelompok Wanita Tani (KWT) Melati Mini atas kerjasama yang baik untuk kelancaran kegiatan.

\section{DAFTAR PUSTAKA}

Anggrodi, H.R. 1995. Nutrisi Aneka Ternak Unggas. Penerbit PT. Gramedia Pustaka Utama, Jakarta.

Makinde, O. J., T. S. B. Tegbe., S. E. Babajide., I Samuel and E Ameh. 2014. Laying Performance and Egg Quality Characrteristics of Japanese Quail (Qoturnic qoturnic japonica) Fed Palm Kernel Meal and Breewers Dryed grain based Diet. Science Education Develompment Institute. 4 $1514-1521$ 
Mirnawati, A Julardi and G Ciptaan. 2018a. Utilization of fermented palm kernel cake with Sclerotium rolfsii in broiler ration. International Journal of Poultry Science. 17 (7) 342 - 347.

Mirnawati, G Ciptaan and A Julardi. 2018b. The effect of palm kernel cake fermentation with Sclerotium rolfsii by adding humic acid in broiler diets. Indian Journal of Animal Scien. 52 (6) : $882-882$.

Mirnawati, A Julardi dan G Ciptaan. 2018. Komposisi dan Proses Produksi Ransum Ayam Ras Petelur Menggunakan Bungkil Inti Sawit dan lumpur Sawit Fermentasi (Paten Terdaftar No. SID201805255).

Rasyaf, M. 2002. Bahan Makanan Unggas di Indonesia. Cetakan IX. Kanisius, Jakarta.

Steel, R. G dan J. H. Torrie. 2002. Prinsip dan Prosedur Statistik, suatu pendekatan biometrik. Gramedia Pustaka Utama, Jakarta.

Tetty. 2002. Puyuh, si Mungil Penuh Potensi. Penerbit PT Agromedia Pustaka, Jakarta.

Wahju, J. 2004. Ilmu Nutrisi Unggas. Gadjah Mada University Press. Yogyakarta. 